\title{
IMPACTOS DAS POLÍTICAS DE FORMAÇÃO DE PROFESSORES NO CURSO DE PEDAGOGIA DA UNOESC (SC): DILEMAS E PERSPECTIVAS
}

\author{
IMPACTS OF TEACHER TRAINING POLICIES IN THE UNOESC (SC) \\ PEDAGOGY COURSE: DILEMMAS AND PERSPECTIVES \\ TÍTULO ABREVIADO: POLÍTICAS DE FORMAÇÃO DE PROFESSORES \\ TEACHER TRAINING POLICIES
}

\author{
Walter Strobel Neto ${ }^{1}$, Maria de Lourdes Pinto de Almeida ${ }^{2}$
}

\begin{abstract}
RESUMO
Este texto é fruto de uma pesquisa realizada no mestrado em Educação da Universidade do Oeste de Santa Catarina cujo objetivo foi de analisar os impactos das políticas de formação de professores sobre os projetos políticos pedagógicos do curso de Pedagogia da Universidade do Oeste de Santa Catarina. A pesquisa foi financiada pelo Fundo de Amparo à Pesquisa da Unoesc e está vinculada a um projeto macro do Grupo Internacional de Estudos e Pesquisas de Educação Superior Unicamp além da Rede Iberoamericana de Políticas e Processos em Educação Superior. A metodologia utilizada para construção desta pesquisa foi a Histórico-Crítica. Como resultados observamos haver uma manipulação de organismos internacionais além do Estado Neoliberal brasileiro, sobre as políticas de formação de professores construídas a partir de interesses voltados ao mercado de trabalho capitalista. Estas imposições podem ser percebidas nas Diretrizes Curriculares dos cursos de Pedagogia, ora privilegiando a pedagogia técnica, ora impondo ajustes não contributivos para áreas de formação como é o caso das licenciaturas.
\end{abstract}

PALAVRAS-CHAVE: Políticas de Formação de Professores. Educação Superior e Pedagogia.

Diretrizes Curriculares Nacionais.

\begin{abstract}
This text is the result of a research carried out in the Masters of Education of the University of the West of Santa Catarina (UNOESC), whose objective was to analyze the impacts of the teacher education policies on the pedagogical political projects of the Pedagogy course of the University of the West of Santa Catherine. The research was funded by the Fund for the Support of Research at Unoesc - (FAPESC) and is linked to a macro project of the International Group of Studies and Research of Higher Education (GIEPES) Unicamp in addition to the Ibero-American Network of Policies and Processes in Higher Education (UNOESC / UNICAMP). The methodology used to construct this research was Historical-Critical. As results we observe a manipulation of international organisms beyond the Brazilian Neoliberal State, on the policies of teacher training built from interests focused on the capitalist labor market. These impositions can be perceived in the Curriculum Guidelines of the Pedagogy courses, sometimes favoring technical pedagogy, sometimes imposing non-contributory adjustments to training areas such as undergraduates.
\end{abstract}

\footnotetext{
${ }^{1}$ http://orcid.org/0000-0003-4068-8164

${ }^{2}$ http://orcid.org/0000-0001-8515-2908
}

\begin{tabular}{l|c|c|c}
\hline Rev. Ciências Humanas & Frederico Westphalen, RS & Pg. 92 - 117 & mai./ago. 2018
\end{tabular}

\begin{tabular}{l|l} 
Recebido em: 30/08/2018 & Aceito em: 17/10/2018
\end{tabular}




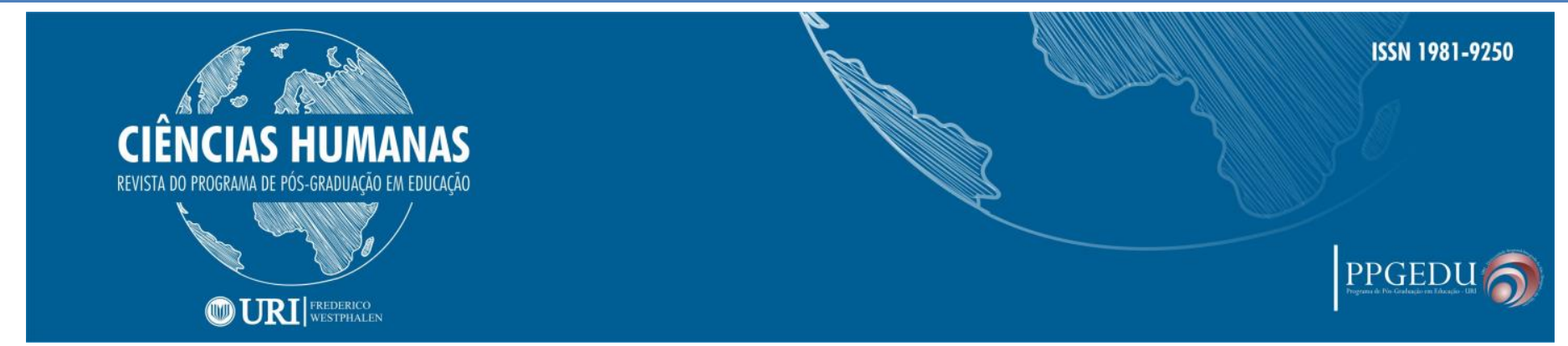

KEYWORDS: Teacher Training Policies. Higher Education and Pedagogy. National Curricular Guidelines.

\section{RESUMEN}

Este texto es fruto de una investigación realizada en el máster en Educación de la Universidad del Oeste de Santa Catarina cuyo objetivo fue de analizar los impactos de las políticas de formación de profesores sobre los proyectos políticos pedagógicos del curso de Pedagogía de la Universidad del Oeste de Santa Catarina. La investigación fue financiada por el Fondo de Amparo a la Investigación de Unoesc y está vinculada a un proyecto macro del Grupo Internacional de Estudios e Investigaciones de Educación Superior Unicamp además de la Red Iberoamericana de Políticas y Procesos en Educación Superior. La metodología utilizada para la construcción de esta investigación fue la Histórico-Crítica. Como resultados observamos haber una manipulación de organismos internacionales además del Estado Neoliberal brasileño, sobre las políticas de formación de profesores construidas a partir de intereses volcados al mercado de trabajo capitalista. Estas imposiciones pueden ser percibidas en las Directrices Curriculares de los cursos de Pedagogía, ora privilegiando la pedagogía técnica, o imponiendo ajustes no contributivos para áreas de formación como es el caso de las licenciaturas.

PALABRAS CLAVE: Políticas de Formación de Profesores. Educación Superior y Pedagogía. Directrices Curriculares Nacionales.

\section{INTRODUÇÃO}

Todas as discussões sempre trazem em suas entrelinhas as orientações de agências internacionais de fomento, a fim de edificar os conceitos neoliberais no Estado Brasileiro. Assim, percebemos que estas impõem um posicionamento de que o professor cumpre um papel secundário na formação, e que as escolas e sistemas educativos devem ser enxugados, o que contribui para o ideário do "aprender a aprender", e da educação à distância. Como ferramenta de exposição da ineficiência do sistema político educacional, estas agências ainda exigem exames periódicos que, posteriormente, são considerados para a qualificação, gerando um ranqueamento e pensamento competitivo entre as escolas. (STROBEL NETO; ALMEIDA, 2017, p. 196-197)

A realidade na formação de professores vem sendo vítima de imposições das novas legislações e diretrizes, pois estas propõem uma reorganização dos cursos de Pedagogia e a alternativa de se fragmentar os conteúdos, trabalhando os mesmos por competências. A discussão dos currículos de formação de professores de todas as licenciaturas repercute no Brasil, pois o tema das reformulações afeta toda a maneira de se construir este futuro professor.

Nesse sentido, faz-se necessário estudar a formação e as licenciaturas, seus componentes, construindo um conceito sobre educação e ensino superior com vistas ao magistério. Assim, discutimos as políticas de educação catarinense, as políticas curriculares e sua inserção na formação. Há a necessidade de uma identidade como

\begin{tabular}{|c|c|c|c|}
\hline Rev. Ciências Humanas & Frederico Westphalen, RS & Pg. $92-117$ & mai./ago. 2018 \\
\hline
\end{tabular}




\section{CIÊNCIAS HUMANAS}

REVISTA DO PROGRAMA DE PÓS-GRADUAĞ̈O EM EDUCAĞ̄o

\section{(1)URI|}

professores para que possamos construir um ideário coletivo, para que não se caia nas armadilhas dos paradigmas. As mudanças históricas auxiliarão na percepção de uma ruptura da modernidade, no campo social, político ou econômico, e como a educação ficou à mercê dos interesses.

A Universidade encontra-se em um dilema entre conceitos da ética e os conceitos do mercado capitalista, e posiciona-se de maneira que deve formar profissionais para a atividade humana, em seus diferentes campos, com vistas aos interesses do mercado formar para que este profissional exerça atividades no mundo do trabalho, por meio de ações que desenvolvam o social que contribuam para com a sociedade, a ética e o desenvolvimento humano.

A discussão a nível internacional aponta para a característica de tecnicidade, vislumbrando vasta preocupação com a especificidade das áreas, posto que este movimento é contrário a uma formação voltada aos aspectos éticos e sociais, característicos de uma formação baseada na formação humana. As ações e reformas na educação superior percebidas nos continentes americano e europeu evidenciam que a discussão da educação é essencial para a prosperidade de uma nação e de sua população, por meio do aumento dos saberes construídos. As observações revelam que os valores éticos devem estar inseridos no âmago das questões trabalhadas nos currículos, e não de forma isolada, a fim de formar um profissional por meio da pesquisa.

As Diretrizes Curriculares Nacionais para os cursos de Pedagogia possuem conflito no momento de compreender a formação universitária. Elas expõem a disparidade no entendimento de que os cursos devem "[...] incentivar uma sólida formação geral, necessária para que o futuro graduado possa vir a superar os desafios de renovadas condições de exercício profissional e de produção do conhecimento, permitindo variados tipos de formação e habilitações diferenciadas" (BRASIL, 2006, p.3). A contradição encontra-se no sentido de que a graduação é percebida como uma formação inicial em um processo constante de formação, no qual os conhecimentos não se esgotam. 


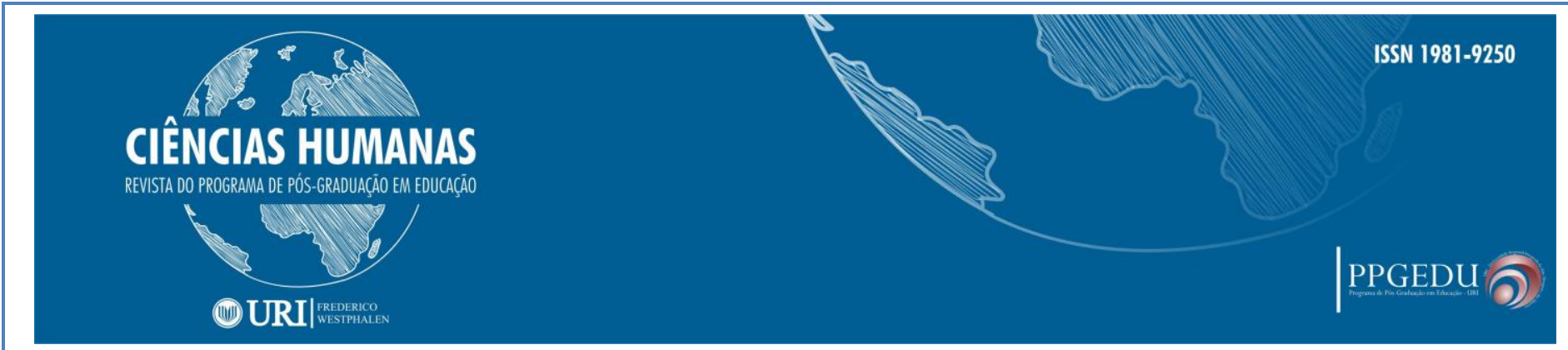

Essas DCN’s determinam um currículo mínimo com várias especificações detalhadas de algumas questões que anteriormente eram mais flexíveis, como carga horária dos componentes e seus conteúdos. A partir destas "orientações", os cursos e universidades iniciaram debates a fim de encontrar soluções para questões estruturais, de fundo prático, de relevância social, de pesquisa, entre outros, por meio de questionamento sobre o que se deve priorizar na formação e como promover as atividades postas.

Assim, as mudanças históricas e das legislações auxiliarão na percepção de uma ruptura no campo social, político e/ou econômico e como a educação encontra-se à mercê de interesses.

Contudo, consideramos que a educação também pode ser um instrumento de marginalização da sociedade, uma vez que é possível manipular o processo. Neste olhar, pode-se considerá-la um gerador de diferenças sociais à medida que não se regulamentam questões comuns aos diferentes níveis de classes. Portanto, de acordo com Saviani (2008, p. 4) a educação deve ser construída como "um instrumento de correção dessas distorções".

Consideramos a educação como a produtora da teoria pedagógica, necessitando de formulações de diretrizes pedagógicas, assumindo posicionamentos políticos, formativos e emancipatórios. Neste sentido, constroem-se as políticas educacionais que são as orientações determinadas pelo Estado, relacionadas com as plataformas educacionais visadas pelos governos. Na elaboração de um projeto de curso superior, essas políticas educacionais guiam e estabelecem diretrizes a serem seguidas, a fim de que o curso possua características instituídas por este Estado.

\section{PROCEDIMENTOS METODOLÓGICOS}

Este artigo tem como objetivo analisar os impactos das políticas de formação de professores, mais especificamente as Diretrizes Curriculares Nacionais (de formação de professores) sobre os projetos políticos pedagógicos do curso de Pedagogia da Universidade do Oeste de Santa Catarina. 


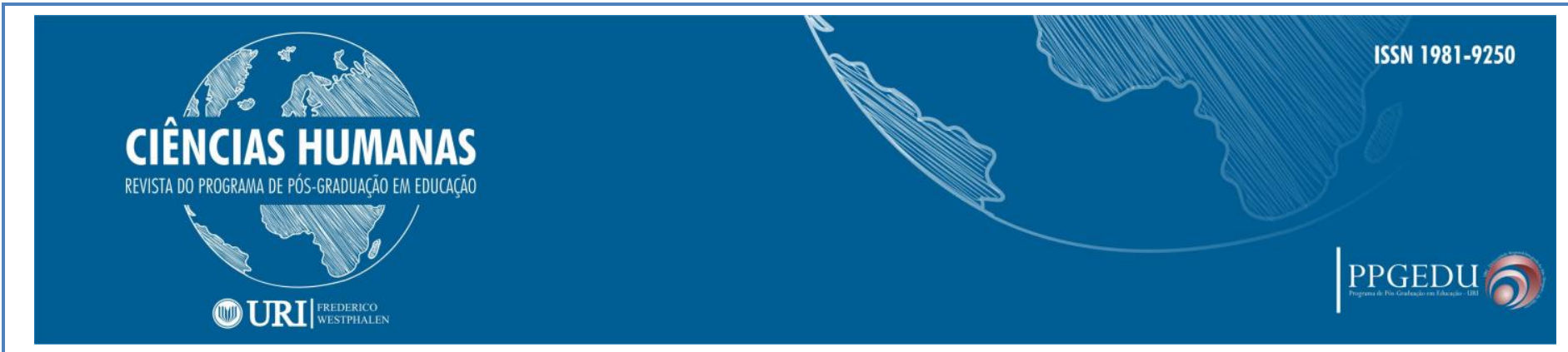

Por meio de caracterizações prévias necessárias à pesquisa, optou-se pelo método histórico-crítico, pois o mesmo atende às necessidades e características inerentes à pesquisa. No que se refere à legitimidade do viés epistemológico da pesquisa, Kosik (2002) esclarece que para legitimar e racionalizar as certezas do mundo é necessário indagar a consciência ingênua no que tange ao tratamento da pesquisa. Justificamos a metodologia trazendo Gasparin (2000, p. 7) quando diz que a metodologia HistóricoCrítica "[...] possibilita então passar do senso comum particular [...] para os conceitos científicos e juízos universais que permitem a compreensão dessa realidade em todas as suas dimensões".

Vale a pena destacar que esta metodologia se empenha a explicar o objeto de análise a partir do desenvolvimento histórico, “ou seja, a compreensão da história a partir do desenvolvimento material, da determinação das condições materiais da existência humana (SAVIANI, 2000, p. 102).

Diante disto, se faz mister retomar o disse Kosik (2002, p. 222):

[...] a práxis na sua essência e universalidade é a revelação do segredo do homem como ser ontocriativo, como ser que cria a realidade (humano-social) e que, portanto, compreende a realidade (humana e não-humana, a realidade na sua totalidade). A práxis do homem não é atividade prática contraposta à teoria; é determinação da existência humana como elaboração da realidade.

Para refletir sobre os impactos das políticas de formação de professores nas tendências curriculares apresentadas nos Projetos Pedagógicos que norteiam o curso de Pedagogia da Universidade do Oeste de Santa Catarina analisamos os Projetos Pedagógicos do Curso de Pedagogia (PPC) de 2006 e 2015, a fim de perceber as influências e os fatores mobilizadores em suas construções. Neste estudo pudemos observar que o PPC de 2004 apresentava várias questões construídas conforme a legislação e, desta forma, traziam o ideário neoliberal em sua essência, como a fragmentação das habilitações do curso de Pedagogia. Assim, este PPC não foi edificado por meio de uma fundamentação metodológica, mas sim apenas tentou, de alguma maneira, atender exatamente ao que a legislação apresentava. 


\section{CIÊNCIAS HUMANAS}

REVISTA DO PROGRAMA DE PÓS-GRADUAĞ̈O EM EDUCAĞ̄o

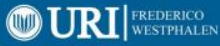

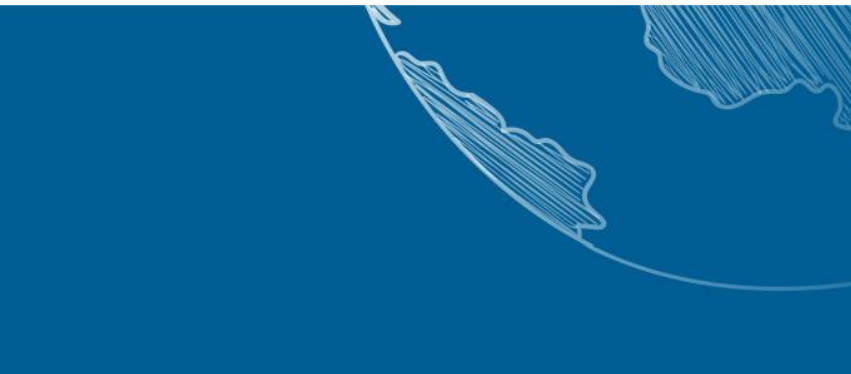

Essa construção da identidade, portanto, estava intimamente ligada com as diretrizes curriculares que obviamente deveriam cumprir naquele, a partir da publicação da resolução e havia obviamente uma dimensão institucional a ser enfrentada.

Neste sentido, na visão de Shigunov Neto e Maciel (2004, p.36), o neoliberalismo é um "projeto político, econômico e social de caráter hegemônico que está fundamentado na subordinação da sociedade ao mercado livre e à não-intervenção do poder público, sendo o mercado livre responsável pela preservação da ordem social".

\section{DILEMAS E PERSPECTIVAS DA FORMAÇÃO DE PROFESSORES A PARTIR DO ESTUDO REALIZADO NOS CURSOS DE PEDAGOGIA DA UNOESC}

O regime neoliberal possui três vértices formando um triângulo, sendo estes o Mercado, o Estado e as Empresas, onde cada um exerce uma força para beneficiar e equilibrar os outros dois, por meio de cortes de despesas e gastos com políticas sociais. Logo, impõe-se uma crise ética e de compreensão científica. Para os olhos do sistema, países como Brasil, México e Argentina deveriam voltar a ser meros exportadores de matéria-prima, controlados totalmente pelo mercado.

Essa crise promove uma percepção "minimalista" de democracia e a coloca como sistema político mascarado, pois é regido por um "economicismo" maquiado por migalhas distribuídas estrategicamente, a fim de manipular. Segundo Anderson (1995, p. 10),

\footnotetext{
O remédio, então, era claro: manter um Estado forte em sua capacidade de romper o poder dos sindicatos e no controle do dinheiro, mas parco em todos os gastos sociais e nas intervenções econômicas. [...] Para isso seria necessária uma disciplina orçamentária, com a contenção dos gastos com bem-estar, e a restauração da taxa "natural" de desemprego [...].
}

Percebe-se então que o cenário dos anos 90 impõe uma diferença e distanciamento entre regime político e desigualdade social, tendo em vista que o neoliberalismo defende o fechamento dos sindicatos, privatizações, redução de impostos sobre altos rendimentos e elevadas taxas de juros. Além disso, assume que nestas situações a 


\section{CIÊNCIAS HUMANAS}

REVISTA DO PROGRAMA DE PÓS-GRADUAC̄̄o EM EDUCAÇ̄o

\section{(1) URI|}

população não possui condições de inserir-se em uma economia mundial e que, para sobressair, é necessário investir em capital humano.

Borón (1995, p. 108) aponta que o sistema proporciona uma paisagem social na qual “[...] o que resta é a estratégia predileta que o neoliberalismo impõe às classes populares: o salve-se quem puder" (grifo do autor). O autor ainda comenta que a atualidade "cheira a farsa política democrática" (1995, p.111).

Neste sentido, Oliveira e Almeida (2011, p. 262) explicam que:

Quanto mais convencido estiver o trabalhador de que a responsabilidade pela sua empregabilidade é pessoal e que seu conhecimento tácito não é relevante, mais se fortalece a competição intraclasse, por consequência, o enfraquecimento da classe trabalhadora é reforçado. Cabe lembrar que, nesse processo, o predomínio do poder é unilateral.

O campo educacional foi brutalmente atingido pela onda neoliberal, pois o sistema reconhece a educação como um meio de libertação, controlando-a e manipulando-a. Os reais interesses do mercado se mantêm, aplicando nas escolas modelos de origem empresarial, utilizando-as como meios de transmissão das ideias neoliberais. Nesse processo, Waismann e Corsetti (2015, p.123) referem que o neoliberalismo incorpora o sistema educacional como foco de atenção para o seu movimento de expansão e de suas formas organizativas materiais, simbólicas e culturais, orientando, segundo a lógica capitalista, o que outrora possuía orientação pública.

A princípio, o posicionamento da educação em contribuir para o crescimento atende à lógica da teoria do capital humano, possibilitando preparar uma força de trabalho educada a fim de melhorar a competitividade entre as empresas. Consequentemente, de acordo com Saviani (2007), se incrementaria o rendimento dos trabalhadores e estes alcançariam riqueza social, dentro de uma lógica coletiva.

Entretanto, Silva (1999) diz que a educação escolar não é uma mercadoria, uma provedora de serviços avaliada por índices da Qualidade Total, transformando o aluno e o mercado em consumidores. Ainda assim, o sistema neoliberal reinterpreta o sentido da satisfação e faz prevalecer os interesses do mercado, posicionando que o trabalhador é 


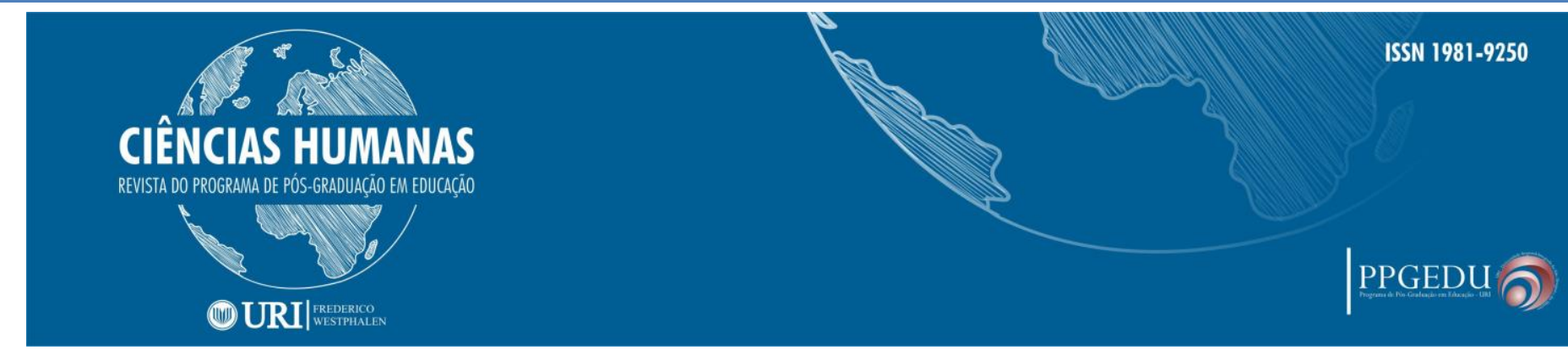

que deve adquirir uma melhor posição no mercado por meio de suas capacidades e competências.

A qualificação, portanto, atrelada desde o modelo de produção tayloristafordista a uma visão contemporânea, abre espaço ao conceito de competência profissional para atender aos conteúdos do trabalho flexível preconizados pelo toyotismo, ainda que se manifeste como um forte mecanismo de inserção profissional e de permanência do trabalhador no mercado de trabalho. (OLIVEIRA; ALMEIDA, 2011, p. 259)

Assim, o Estado se distancia da responsabilidade pelo futuro da educação e retira seu compromisso com a universalização. Vale ressaltar o posicionamento de Gentili (2009, p.1063) quando chama a "universalização das oportunidades de acesso à escola de uma "universalização sem direitos"”. O autor (GENTILI, 2009, p.1064) define três fatores que produzem este movimento:

a) a combinação e articulação de condições de pobreza e desigualdade vividas por um significativo número de pessoas em nossas sociedades; b) o desenvolvimento fragmentado dos sistemas escolares e os enormes diferenciais de oportunidades que as escolas oferecem; c) a promoção de uma cultura política sobre os direitos humanos - e particularmente sobre o direito à educação - marcada por uma concepção privatista e economicista que, longe de ampliar, restringe as fronteiras desse direito às oportunidades de acesso e permanência no mercado de trabalho.

Esse distanciamento impacta na formação dos professores, por meio das bases curriculares dos cursos de licenciatura, mais especificamente os de Pedagogia, trazendo um novo formato de cursos para as universidades. Nesse sentido, Shigunov Neto e Maciel (2004, p. 56) comentam:

A escola não pode ser comparada a uma empresa, pois, apesar de possuir inúmeros elementos que a aproximam daquelas, seus objetivos não são idênticos. O seu objetivo não é a obtenção de lucros, e os resultados a serem alcançados - a formação do homem e do trabalhador - são de longo prazo.

Para o neoliberalismo, o trabalhador necessita de conhecimento para a resolução de problemas lógicos, ser avaliado por competências e habilidades e, por isso, o ensino exerce importante papel. A partir deste momento, implanta-se a teoria do conhecimento, sendo este o diferencial entre os trabalhadores. Outro posicionamento é o das relações 


\section{CIÊNCIAS HUMANAS}

REVISTA DO PROGRAMA DE PÓS-GRADUAĞ̈O EM EDUCAĞ̄o

\section{(1) URI|}

entre os envolvidos no processo, para o qual a escola, o professor e os alunos adotarão práticas diferenciadas. Por meio destas práticas, que valorizam a experiência e o saber resolver, aumenta-se a carga horária de componentes ligados a estágios e, consequentemente, encurtam-se os conteúdos teóricos nos currículos. Consequentemente, existe uma diminuição e fragmentação do desenvolvimento da pesquisa científica de cursos considerados mais teóricos, como as licenciaturas, em contrapartida do crescimento de cursos voltados às áreas técnicas, como as engenharias.

Além do direcionamento dos conteúdos priorizados neste contexto, Silva (2002) considera que este sistema tende a contribuir para a fragmentação, a individualidade, a competitividade e a produtividade, enfraquecendo as instituições educacionais públicas. Estas, segundo a autora, exercem a função de espaços de reflexão e crítica, contribuindo para a formação. Assim, os cursos de licenciatura também sofrem, pois são "alternativas" pouco valorizadas no universo neoliberal, onde o professor, pouco valorizado pelo mercado e consequentemente pelas políticas, atrai, segundo Silva (2002, p. 70):

[...] alunos com formação intelectual incompleta e com condições sociais econômicas comprometidas, e estes tornam-se professores com habilitação, mas com formação deficitária, que irão atuar na escola pública [...] Essa circularidade tem também origem em outros fatores: no tratamento de desqualificação dado pelo governo a esses profissionais, nas políticas de redução salarial, no desestímulo à dedicação exclusiva e flexibilização dos contratos de trabalho, no desemprego estrutural, na ausência de perspectiva, na degeneração social e na submissão às políticas externas.

Uma vez que o foco da formação dos professores é o de desenvolver as competências e habilidades nos alunos, as DCN's para o curso de Graduação em Pedagogia, licenciatura, instituídas pela Resolução CNE/CP $\mathrm{n}^{\circ} 1$, de 15 de maio de 2006, trazem diversos apontamentos de como deve ser conduzido. O que se percebe é o aumento de conteúdos voltados à construção do ser humano, composto por fatores sociais e familiares que influenciarão em sua formação. Assim, os conteúdos voltados às teorias ficam marginalizados dentro do atendimento de uma carga horária mínima sugerida como dispõe o artigo $7^{\circ}$ (BRASIL, 2006, p. 4): 


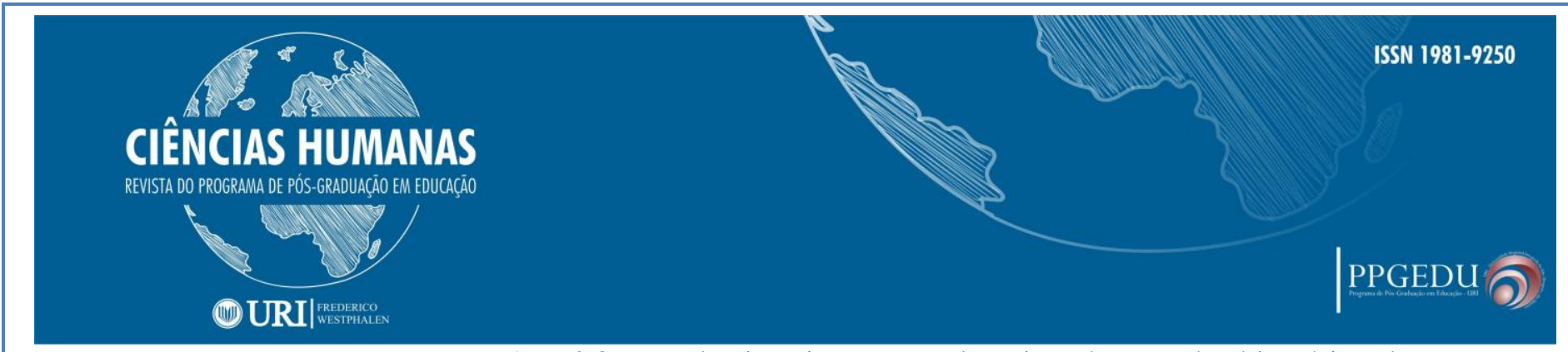

Art. $7^{\circ} \mathrm{O}$ curso de Licenciatura em Pedagogia terá a carga horária mínima de 3.200 horas de efetivo trabalho acadêmico, assim distribuídas: I - 2.800 horas dedicadas às atividades formativas como assistência a aulas, realização de seminários, participação na realização de pesquisas, consultas a bibliotecas e centros de documentação, visitas a instituições educacionais e culturais, atividades práticas de diferente natureza, participação em grupos cooperativos de estudos; II - 300 horas dedicadas ao Estágio Supervisionado prioritariamente em Educação Infantil e nos anos iniciais do Ensino Fundamental, contemplando também outras áreas específicas, se for o caso, conforme o projeto pedagógico da instituição; III - 100 horas de atividades teórico-práticas de aprofundamento em áreas específicas de interesse dos alunos, por meio, da iniciação científica, da extensão e da monitoria.

Outra orientação que permeia o documento é que para esta formação psicológica, o estudante de Pedagogia deve participar de atividades relacionadas à Escola, em um modelo de estágio, diretamente ligado ao cotidiano da prática de sala de aula. Desta maneira, o aluno de Pedagogia, nos semestres iniciais, transforma-se em mero expectador na Escola. Com o afastamento da teoria de seu currículo, ele observa as atividades no Estágio, mas não possui conhecimento teórico que possa nortear seu olhar e possibilitar a construção de questionamentos quanto ao que está sendo observado. A este respeito, Borges (2010, p. 35) alerta:

É preciso problematizar essa equivalência admitida para os professores em processo de formação que, ao mesmo tempo, já contabilizaram alguma experiência docente. É bem certo que a instituição formadora não poderá ou desconsiderar tal experiência, entretanto, esta não pode ser reduzida a uma relação linear de equivalência de créditos a serem integralizados no fluxo curricular do professor estudante, ao contrário, deverá ser objeto de reflexão e significação da mesma prática que se quer consolidar.

Outra consequência das DCN’s orientando o aumento da carga horária das atividades práticas e a consequente diminuição de conteúdos teóricos dentro do limite total de horas do curso, possibilita o falecimento de questionamentos relacionados a pesquisas científicas na área. Desta maneira, cada vez mais o professor se forma olhando para as necessidades momentâneas do mercado, como um técnico em educação, e deixa de interessar-se por uma das atividades do pedagogo, a pesquisa. Esta passa a ser uma opção do indivíduo, responsável em continuar a construção de seus conhecimentos, retirando a responsabilidade do Estado quanto à formação, que passa a ser mínima, desenvolvendo um trabalhador independente e praticamente autodidata. \begin{tabular}{l|c|c|c}
\hline Rev. Ciências Humanas & Frederico Westphalen, RS & Pg. 92 - 117 & mai./ago. 2018
\end{tabular} Recebido em: 30/08/2018 $\quad$ Aceito em: 17/10/2018 


\section{CIÊNCIAS HUMANAS}

REVISTA DO PROGRAMA DE PÓS-GRADUAĞ̈O EM EDUCAĞ̄o

\section{(1)URI|}

Este posicionamento atinge e transforma a função da escola dentro do sistema, posto que o Estado não mais se responsabiliza em preparar a mão-de-obra para o mercado, pois agora esta incumbência é do próprio indivíduo, que deve especializar-se para uma vaga de emprego. O Estado, eximindo-se, faz com que haja uma diferenciação nas condições de empregabilidade, pois somente aquele que possui condições de especializar-se é que conseguirá as vagas. Esta situação semeia o distanciamento do desenvolvimento social, pois enfatiza que aqueles que não possuem condições de estudar não estarão aptos a concorrerem a um emprego aumentando, consequentemente, as taxas de desemprego.

A adoção do modelo neoliberal construiu um distanciamento do Estado como formador de uma melhor condição humana e o aproximou das propostas exigidas pelos órgãos internacionais. Desta maneira, em um posicionamento de Estado regulador, construiu um conjunto de Leis e Diretrizes que chancelam a exclusão do indivíduo por meio da educação, pois a qualidade transforma-se em privilégio, promovendo uma "pedagogia da exclusão". Estas novas legislações com olhares diferenciados tiveram impacto na forma como os envolvidos no processo da educação trabalhavam, pois o Estado, a Escola, os Professores e os conteúdos deveriam reposicionar-se diante da nova situação implantada. Nesta condição, Saviani (2007, p. 431) vê “[...] o alargamento do horizonte da educação que coloca para a escola exigências mais amplas".

A partir deste momento, como o Estado não é mais o responsável pela educação e, sim, pela sua regulamentação, difunde-se que o indivíduo é o responsável por sua formação, e este agora deve "aprender a aprender". Essa base pedagógica remete às ideias do escolanovismo, alterando o foco do processo educativo para questões relacionadas ao esforço e ao interesse individual, sendo importante aprender a buscar novas soluções para novas situações. O aluno é o responsável pelo seu processo de aprendizagem e o professor deixa de ensinar, passando auxiliá-lo, como entendem Shigunov Neto e Maciel (2004, p. 63), "transferindo para ele a responsabilidade pelo sucesso ou pelo fracasso". Esta concepção leva a uma construção totalmente diferenciada do posicionamento docente e de como o mesmo deve lidar com estas outras demandas. 


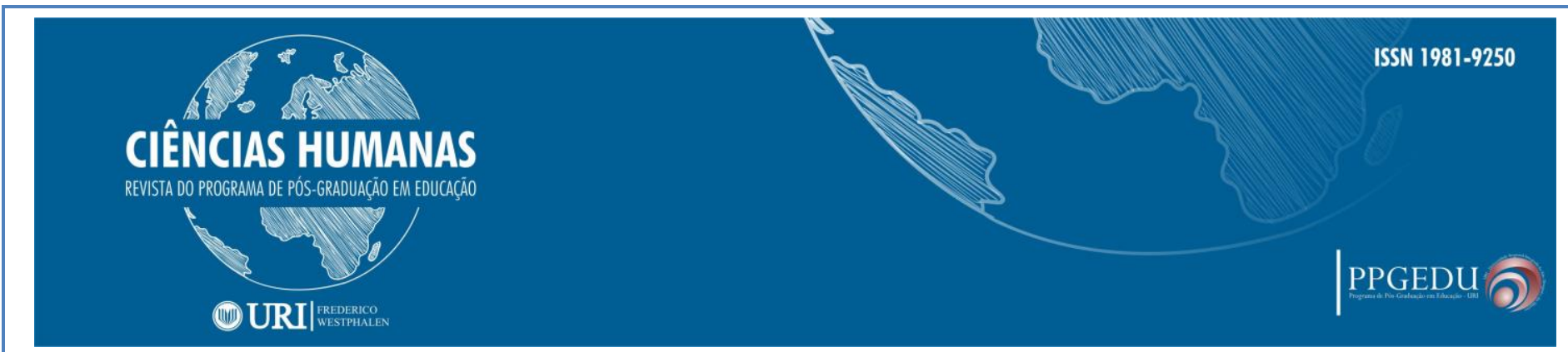

Consequentemente, a formação deste professor também fica refém da nova ordem de globalização, sofrendo profundas mudanças assim como todo o sistema educacional, pois em uma lógica voltada ao mercado a crise se apresenta em diversas frentes. A formação, neste sentido, teve que ser repensada, uma vez que o professor não exerce a posição daquele que ensina, mas sim a de um tutor que auxilia o aluno no seu processo de aprender a estudar, a solucionar problemas. Assim, os cursos de Pedagogia reestruturaram-se para um viés com conteúdos de características mais psicológicas, cognitivas, pois o aluno deve adaptar-se a sua nova sociedade, que exige novos tipos de comunicação e raciocínio. Além da formação do professor, também foi necessário reposicionar a escola para as mudanças políticas e legislativas, norteando sua função por intermédio de interesses estatais.

As Instituições de ensino são regidas pela Lei de Diretrizes e Bases da Educação (LDB 9394/96), em consonância com o pensamento neoliberal, permitindo que o poder empresarial e o capital imponham os caminhos a seguir para atender uma necessidade própria. Visando à formação de um profissional capacitado tecnicamente, com vistas à competitividade e à produtividade, Frigotto (2001, p. 64) identifica que o "[...] o BM consiste, hoje, no intelectual coletivo formulador da política educacional para os países que necessitam de ajuste estrutural, dando as diretrizes da organização, as prioridades e os conteúdos".

Assim, as Instituições de Ensino Superior (IES) são o meio de integração do indivíduo ao mercado de trabalho, como instrumento do aumento da riqueza. Para o mercado, quanto mais estudo, maior será o salário, promovendo crescimento econômico e diminuição da pobreza, como esclarecem Mccowan e Schendel (2015, p. 21): “O papel hoje preeminente do diploma universitário como um mecanismo de classificação para o empregado tem colocado uma pressão crescente sobre as universidades para formar profissionais e trabalhadores para o mercado de trabalho".

Tendo como foco a formação do professor, lida-se com o questionamento de qual escola o sistema pretende construir para que este futuro professor atue. Nesse caso, a formação é de suma importância para o Estado, pois a educação será responsável por implantar e defender as ideias do sistema. Para tanto, o Estado cada vez mais se afasta

\begin{tabular}{|c|c|c|c|}
\hline Rev. Ciências Humanas & Frederico Westphalen, RS & Pg. $92-117$ & mai./ago. 2018 \\
\hline
\end{tabular}




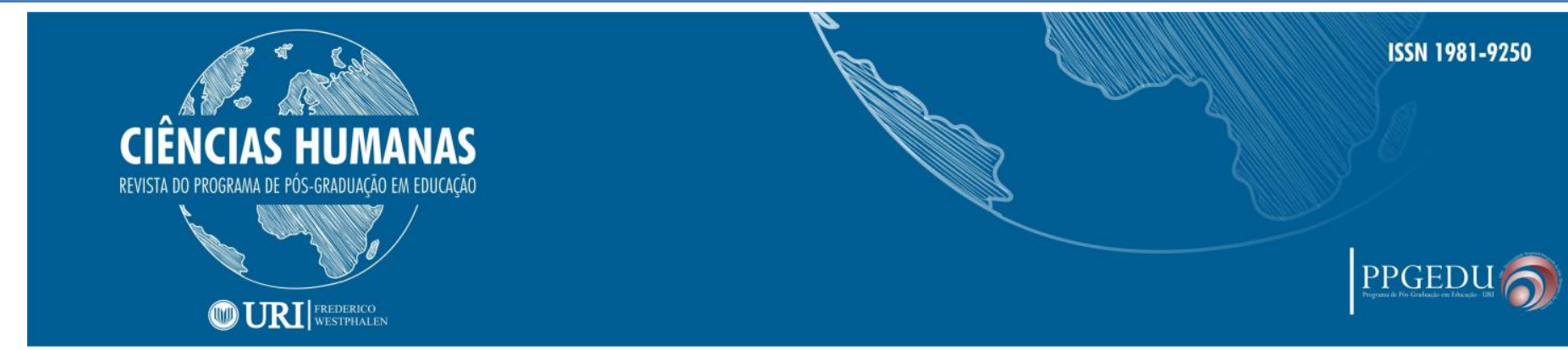

da posição de gestor, configurando-se como um regulador do sistema, implantando e avaliando ações norteadas pelo mercado, a fim de manter o controle e diminuir suas despesas. Essa avaliação está intrinsicamente relacionada à formação do professor, uma vez que os cursos universitários sofrem constantes verificações, em diferentes níveis, pelos órgãos competentes.

Todos estes apontamentos influenciam no funcionamento e direcionamento do processo como um todo, por meio da competitividade e sucateamento das Instituições Públicas, aumento o favorecimento da abertura e manutenção de Instituições Privadas. Juntamente com suas consequências, figura a não valorização do professor da Educação Superior, forçando-o a competir com os colegas, característica do sistema neoliberal, além do posicionamento pedagógico e de conteúdos que as legislações impõem aos cursos, como explicam Waismann e Corsetti (2015, p.136):

[...] o mercado da educação superior aumenta as suas matrículas, contrata mais professores, porém menos que o crescimento das matrículas, ou seja, intensifica o trabalho docente e remunera a força de trabalho (docentes) com quase um quarto a menos de salário. Pode-se então perceber que a realidade da educação superior comportava profissionais mais qualificados, trabalhando mais e ganhando menos.

A partir da reforma do Estado Brasileiro, em 1995, as principais diretrizes do governo Federal foram a privatização, a terceirização e a publicização. Essa reforma, alinhada com o discurso neoliberal, teve a finalidade, nas palavras de Chaves (2010, p. 482-483) de reduzir o "tamanho do Estado", diminuindo sua presença na área social e produtiva

[...] na área educacional, a política de focalização se manifesta por meio da priorização dos recursos da União para o atendimento ao ensino fundamental; pela criação de bolsas de estudo para os estudantes do ensino superior privado; e pela redução dos investimentos públicos nas instituições de ensino superior (IES) públicas, introduzindo-as à captação de recursos no mercado capitalista. Assim, a educação superior deixa de ser direito social, transformando-se em mercadoria. A tese é a de que o sistema de ensino superior deve se tornar mais diversificado e flexível, objetivando uma expansão com detenção nos gastos públicos. 


\section{CIÊNCIAS HUMANAS}

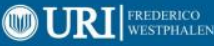

A autora ainda enfatiza que a expansão das instituições privadas teve como vantagens isenções fiscais e autorização de oferta de cursos aligeirados. Todas as ações sempre foram vinculadas ao ensino e desvinculadas da pesquisa.

Nesse contexto, a formação de professores foi transformada naquilo que vários autores chamam de treinamento, em um contexto que se volta à escola básica formadora de massas e no atendimento ao aluno, por meio de uma educação preocupada com a relação ensino e aprendizagem, teoria e prática. Este direcionamento à educação básica tornou a formação de professores precária e frágil, no sentido de que a escola limitou-se à função se ensinar (VEIGA, 2009).

Tais medidas vão ao encontro do posicionamento neoliberal, retirando a responsabilidade do Estado em prover a educação, repassando-a ao setor privado, em uma maneira legalizada de terceirização do setor. Mais uma vez todos os envolvidos no processo educacional, como Instituição, professor e aluno são vistos como mercadoria, disputando entre si condições alternativas de um discurso cujo objetivo é o lucro, a barganha e captação de recursos financeiros, onde o que menos tem valor é a qualidade da educação voltada para o mundo do trabalho e não para o mercado capitalista.

Como alternativa para o cenário construído, planejado e apocalíptico, o filósofo Mészáros (2005) em sua obra A educação para além do Capital defende que a educação pode mudar e possui condições para mudar o rumo de uma sociedade atrelada às essências que priorizam a emancipação. Sendo assim, aponta que a escola deve romper drasticamente com o sistema capitalista e parar de reforçar o discurso do capital, rasgando a "camisa de força" que este aplica sobre a sociedade por meio de uma massificação do ensino. Nas palavras do autor (MÉSZÁROS, 2005, p. 27) “[...] é necessário romper com a lógica do capital se quisermos contemplar a criação de uma alternativa educacional significativamente diferente".

Para tanto, este autor, esclarece que a educação não ocorre somente no ambiente escolar e que esta deve ser trabalhada em ambientes não formais de educação. A identificação é que para o real rompimento com o capital, o indivíduo deve alterar a sua essência e em ambientes não formais ela realmente pode ser construída. Assim, a família, os amigos, a literatura, todas as atividades contribuiriam para tal conquista, 


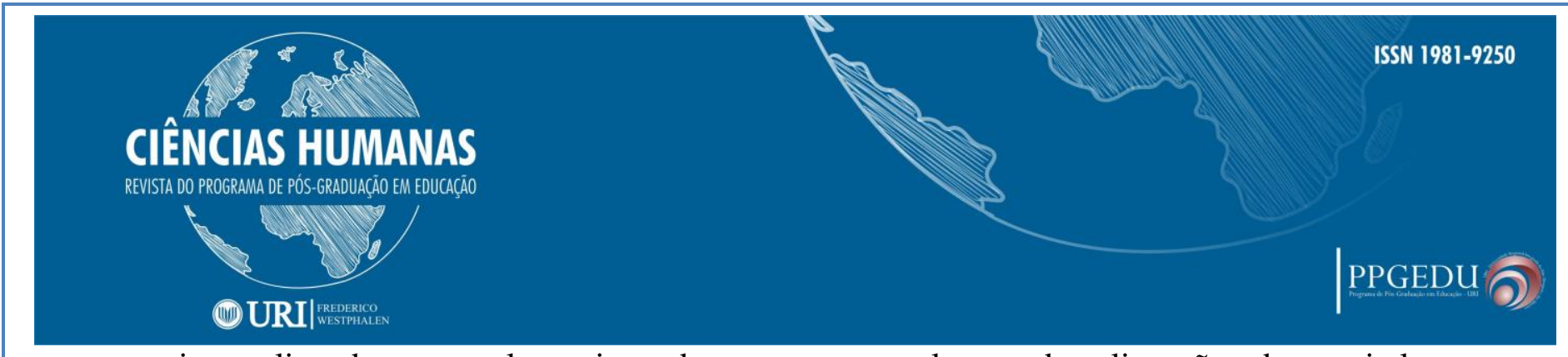

internalizando uma alternativa abrangente para longe da alienação do capital (MÉSZÁROS, 2005)

Dessa maneira, a construção do ser humano seria durante toda a sua vida, pois as ideias e posicionamentos quanto a qualquer situação são constantes e essas decisões constroem o indivíduo. Mészáros (2005, p. 49) ainda identifica que o capital, conhecendo estes valores, embute suas ideias e quase amputa a diversidade de possíveis linhas de posicionamento político "contra uma concepção tendenciosamente estreita da educação e da vida intelectual, cujo objetivo obviamente é manter o proletariado "no seu lugar"",

Percebe-se a teoria do autor quando visualizamos o processo que constrói as DCN’s dos cursos de graduação. Estas, como já exposto, são elaboradas em modelos que forjam no indivíduo um raciocínio técnico, limitado em questionamentos emancipatórios, mantendo-o sob certo controle. De certa maneira, estas ações poderiam ser consideradas como uma forma de escravidão por meio de uma frágil e direcionada educação.

Por meio desses embates de direcionamentos norteados por interesses contrapostos, evidenciam-se contradições na construção e efetivação de políticas, segundo evidencia Freitas (2007, p.1223):

Os desafios para os setores progressistas aumentam, na medida em que os
"interlocutores válidos", escolhidos nessa caminhada, não são os sujeitos do
processo educativo, aqueles que, nas escolas e nas universidades, deveriam
ser partícipes ativos na construção das políticas educacionais que constroem
ou destroem as suas vidas: os professores, os estudantes, os educadores da
escola e os pais. As continuidades que se estabelecem entre governo e esferas
da sociedade civil, para a construção do PDE, sinalizam nova configuração
aos processos de gestão da educação e da escola, ao ensino e ao trabalho
docente, que merece ser examinada a muitas, muitas mãos.

Diante desses posicionamentos, faz-se necessária a discussão sobre a construção de novos cursos, elaborados com uma maior participação de alunos e professores. É importante a elaboração de conteúdos básicos, comuns e de caráter ético, para que a independência das escolhas não prejudique a formação básica da filosofia, não como disciplina, mas como forma de perceber um mundo em construção, discernimento necessário ao futuro professor. Além da participação, é importante ressaltar que esta \begin{tabular}{c|c|c|c}
\hline Rev. Ciências Humanas & Frederico Westphalen, RS & Pg. 92-117 & mai./ago. 2018 \\
\hline Recebido em: $30 / 08 / 2018$ & Aceito em: 17/10/2018
\end{tabular} 


\section{CIÊNCIAS HUMANAS}

REVISTA DO PROGRAMA DE PÓS-GRADUAĞ̈O EM EDUCAĞ̄o

\section{(1) URI|}

alternativa de trabalho deve ser norteada por delimitações curriculares orientadoras, além de princípios como o método, os conteúdos, as relações entre as diferentes fases educacionais e a teoria e a prática.

Diante do exposto, podemos compreender que que conseguimos caracterizar uma situação que já está posta, e que está totalmente voltada para o mercado de trabalho, a mercantilização da profissão do docente além da valorização da competitividade como fator de crescimento educacional e profissional. Diante deste cenário, se faz mister construir uma percepção de que o docente e a escola são fatores importantíssimos na formação do sujeito histórico. Neste cenário, o processo de formação de professores deveria ser livre dessas amarras ideológicas pregadas e trazidas pelo sistema capitalista.

Com a identificação de que o mercado se fortalece, acumulando produtos, aumentando as riquezas, a escola passa a assumir um novo posicionamento, devendo adaptar-se para não formar apenas um trabalhador, como sinaliza Freitas (2007, p. 1225):

A construção de novos processos formativos, que respondam às exigências e necessidades sociais na atualidade, se situa no campo das contradições e das lutas pelo anúncio de uma outra sociedade, justa e igualitária, de progresso e emancipação. É o que nos move nestas circunstâncias.

O conflito perpassa todos os envolvidos, principalmente no que tange à formação dos professores que irão educar neste cenário histórico caótico, desconstruído pós golpe de agosto de 2016, imposto por um governo temeroso e totalitário. Este contexto, traz como consequência uma queda dos valores de investimento e das condições de trabalho nos cursos de pedagogia, com uma diminuição significativa na procura dos estudantes de ensino médio pela docência.

De acordo com Silva (2002, p. 165), a (des)qualificação do educador e a falta de condições adequadas são fatos perversos que a história apresenta a décadas em nosso país. Ademais:

A formação de profissionais que a sociedade demanda encontra-se imersa na questão: formar profissionais qualificados que incorporem o arcabouço teórico disponível, mas que assimilem e saibam decodificar a multiplicidade de práticas e de aprendizagem essencialmente humanas, utilizando-se com critério as tecnologias. 
Pela visão neoliberal "adotada" nas políticas públicas, inteligentemente o sistema educacional percebe que o professor é um formador de opinião por meio da formação teórica, social e cultural, passando a repensar ou impor amarras ideológicas mascaradas nas supostas ações e diretrizes curriculares. O que realmente interessa ao sistema educacional regido pelo Estado Neoliberal Brasileiro é ter uma educação lucrativa, vista como bens de consumo e estes fabricados por profissionais de tenham a característica técnica, possibilitando o enriquecimento dos conglomerados capitalistas, controlando as massas com falsos instantes de uma pseudo estabilidade financeira, trazendo bônus e recompensas pós realização de avaliações em larga escala no chão da escola

Maués (2015) apresenta várias provas deste posicionamento dos órgãos mundiais que a educação deve possuir em um país que pretende se desenvolver no quesito ranking educacional. A autora, em seu livro, apresenta trechos de um documento publicado em 2008 pela Organização para Cooperação e Desenvolvimento Econômico (OCDE), que claramente tem por objetivo a preparação do professor voltada ao mercado de trabalho, posicionando-o como um pilar crucial a fim de aumentar o capital do país. Ainda Maués (2015, p. 210), esclarece que aumentando o conhecimento, consequentemente o país será mais competitivo, relacionando "ensino, salário e desempenho econômico".

Nesta crise de identidade, as IES necessitam reestruturar seus objetivos e posicionamentos, adotando o discurso de uma "nova" cultura acadêmica. Essa caminhada deverá observar questões importantes como novas normas éticas, novas tarefas da docência, novo posicionamento das investigações e novas construções de extensões. Sobre o assunto, Sguissardi (2008, p.1013) elucida que, sem estas relações, as Instituições não terão condições de sobreviver, desmantelando o posicionamento da Universidade como um espaço de disputas:

A proeminência do mercado-educacional no modelo de expansão da educação superior, como demonstrado, em que tende a impor-se, no médio prazo, a hegemonia do setor privado-mercantil - IES e matrículas -, exige que se ultrapasse o campo empírico e se tente alcançar a essência desse fenômeno. Como corolário da tendência de tudo ser transformado em mercadoria pela sociedade capitalista, é que se pode entender que os serviços educacionais, como um direito e um bem público, possam ser considerados como uma mercadoria, a educação-mercadoria, objeto de exploração de mais- 


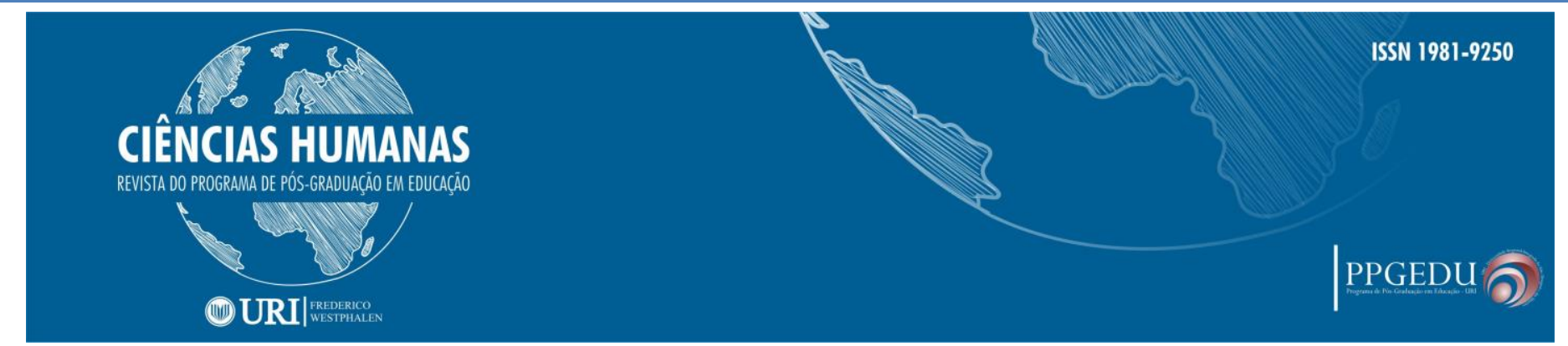

valia ou de valorização. Isto não somente entre os empresários da educação, mas até certo ponto também para os interesses privado/mercantis no aparelho do Estado.

E é por meio destas políticas de formação que estes docentes estão tendo que, como mencionado, buscar novas qualificações, mas com o objetivo de se ter seu crescimento profissional no quadro de carreira docente.

A visão mercadológica da competitividade imposta pelo mercado exigiu que, por meio da LDB de 1996, todos os professores da Educação Básica fossem portadores de um diploma de Ensino Superior. A corrida pela formação superior desencadeou uma onda de cursos de licenciaturas com qualidade questionável, sendo muitos na modalidade a distância, como antes referido. Com foco contrário ao de uma formação emancipatória, a formação transforma professores em administradores, burocratas e operadores de uma sistemática que exclui a identidade social do educador. Assim, como constatam Veiga e Viana (2010, p. 17), a formação:

[...] se resumiu à transmissão rápida de conhecimento, habilitação relâmpago de professores por meio de treinamento, do adestramento, dosando e qualificando resumidamente o conhecimento até chegar à informação técnico-instrumental de um fazer acrítico e alienado.

A alternativa foi resolver quantitativamente os números impostos pelos órgãos internacionais, mas como consequência previsível e posicionamento consciente, esta formação aligeirada inseriu no mercado, dentro das salas de aula, muitos até então somente técnicos, agora com um diploma superior. Como já exposto, esta resulta em uma formação desigual, uma vez que para se alcançar os números desejados, o Estado incentivou a abertura de muitos Cursos de Pedagogia à Distância, construindo uma massa de professores despreparados e sem o compromisso com a pesquisa e com o desenvolvimento da educação.

\section{(DES) CONSIDERAÇÕES FINAIS}

A opção governamental de implantar uma doutrina que privilegie apenas uma parcela da sociedade fez com que conceitos de instituições devessem ser discutidos.

\begin{tabular}{l|c|c|c}
\hline Rev. Ciências Humanas & Frederico Westphalen, RS & Pg. 92 - 117 & mai./ago. 2018 \\
\hline
\end{tabular}

\begin{tabular}{l|l} 
Recebido em: 30/08/2018 & Aceito em: 17/10/2018
\end{tabular}




\title{
CIÊNCIAS HUMANAS
}

REVISTA DO PROGRAMA DE PÓS-GRADUAĞ̈O EM EDUCAĞ̄o

\section{(1) URI|}

Neste sentido, a Universidade passa por um grande debate frente ao Neoliberalismo, absorvido pelo Brasil nos anos 1990.

A razão da existência das Instituições de Educação Superior, reside nas discussões e estudos a fim de melhorar a qualidade de vida de uma sociedade civil, porém, o regime proposto ao final do século $\mathrm{XX}$ defende uma liberdade do mercado em contrapartida a minimização do Estado comparada a economia. Essa situação proporciona várias atritos entre a natureza universitária e a imposição das demandas do mercado, fazendo com que o público deixe de contribuir com as novidades conceituais, para realizar inovações para fins comerciais, ditadas pelo capital. E a formação de professores não foge deste contexto.

Diante da legislação camuflada com conceitos capitalistas, sentimos a necessidade de debater os impactos das politicas de formação de professores no curso de Pedagogia da UNOESC, mais especificamente, via Diretrizes Curriculares Nacionais.

Assim, realizamos um estudo sobre as políticas curriculares para o ensino e como estas foram influenciadas pelo ideário neoliberal como, por exemplo, a LDB de 1996. $\mathrm{Na}$ sequencia, estudamos a legislação para o ensino superior e para os cursos de Pedagogia.

Para nortear a investigação, elegemos a metodologia histórico-crítica, que propõe um movimento em várias fontes de pesquisa, a fim de perceber a realidade não apresentada ao homem, o que Kosik (2002, p.13) define como a "coisa em si" que

\begin{abstract}
[...] não se manifesta imediatamente ao homem. Para chegar à sua compreensão, é necessário fazer não só um esforço, mas também um détour. Por este motivo o pensamento dialético distingui entre representação e conceito da coisa, com isso não pretendo apenas distinguir duas formas e dois graus de conhecimento da realidade, mas especialmente e sobretudo duas qualidades da práxis humana.
\end{abstract}

Todas as discussões trazidas no discurso do Estado, trazem em suas entrelinhas as orientações de agências internacionais de fomento, a fim de edificar os conceitos neoliberais no Estado Brasileiro. Assim, percebemos que estas impõem um posicionamento de que o professor cumpre papel secundário na formação, e que as escolas e sistemas educativos devem ser enxugados, o que contribui para o ideário do 


\section{CIÊNCIAS HUMANAS}

REVISTA DO PROGRAMA DE PÓS-GRADUAĞ̈O EM EDUCAĞ̄o

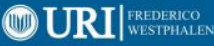

aprender a aprender, e da educação à distância. Como ferramenta de exposição da ineficiência do sistema público educacional, estas agências ainda exigem exames periódicos que, posteriormente, são considerados para a qualificação, gerando um ranqueamento e pensamento competitivo entre as escolas.

Infelizmente o professor, na maioria das vezes, é considerado como um operário tarefeiro e, portanto, este pode ser formado apenas com conhecimentos técnicos e em instituições que não se preocupam com outras esferas da construção do conhecimento, como a pesquisa e a extensão. Este nivelamento "por baixo" da formação de professores e massificação da mesma, com custos mínimos, é estudado por Freitas (2007) que identifica na legislação o que posteriormente se confirma nas ações, como a formação continuada do professor por meio do ensino à distância, favorecendo uma pseudo sociedade do conhecimento e de crescimento intelectual, reduzindo espaços científicos e fundamentações epistemológicas.

Este estudo identificou que a doutrina neoliberal considera a educação uma ameaça e impõe, por meio da legislação, suas ideologias. Diante disto, o campo educacional luta por discussões a fim modificar ou contornar tais ideários e contribuir para uma formação de alunos e professores ética e de peso social.

Saviani (2007) lembra que o impacto no setor educacional foi gigantesco, pois considera que a educação contribui para a construção do ser humano crítico e reflexivo, o que é inconcebível para o neoliberalismo. Desta maneira, o sistema precisou optar por estratégias que visam desmantelar esta construção, por meio da fragmentação, da individualidade entre os pares, da competitividade e do esvaziamento do poder público na educação. Observamos que estes conceitos se fazem presentes na legislação aprovada durante e após os anos 1990, não valorizando os cursos voltados à área das humanidades. Como exposto, observamos a questão da fragmentação muito presente na proposta do PPC 2004 da Unoesc, que contava com cinco habilitações diferentes para o curso de Pedagogia.

Diante do cenário, a formação do professor sofre tanto quanto a educação, pois os mesmos pensamentos mercadológicos servirão de conceituação para com as legislações 


\section{CIÊNCIAS HUMANAS}

REVISTA DO PROGRAMA DE PÓS-GRADUAĞ̈O EM EDUCAĞ̄o

\section{(1) URI|}

responsáveis por aqueles que formarão os estudantes, sugerindo ações que levam ao treinamento de professores, como já refletido anteriormente.

Outra possível alternativa para romper com o ideário neoliberal presente nas diretrizes curriculares é fazer com que o professor se perceba como um agente social, por meio de concepções críticas de educação, discutindo a globalização em um projeto coletivo. Para Veiga (2009) devemos formar professores que compreendam seu papel como docente, como um formador, crítico e reflexivo.

O desenho dos fatos históricos foi revelador nas questões históricas sobre os posicionamentos políticos e como estes refletiram na formação de docentes, conforme a época e os interesses do momento.

As legislações implantadas por meio da LDB de 1996 e das Diretrizes Curriculares Nacionais para a formação de professores da educação básica, em nível superior, curso de licenciatura de graduação plena, anunciadas pelas resoluções do CNE/CP n.1 e n.2 (2006), apresentavam pensamentos do ideário neoliberal, e conflitos gerados no meio educacional.

Assim, o Projeto Político do Curso de Pedagogia de 2006 foi construído em uma lógica de Blocos e Núcleos, a fim de possibilitar a integração do PPC da Pedagogia com os PPC's de outras licenciaturas. Neste sentido, a proposição foi construir um Bloco de conteúdos comuns, com orientações sobre a formação do docente, pois pelo entendimento do grupo, todos os cursos de licenciatura formavam docentes. Desta maneira, este bloco comum possibilitaria a complementação interdisciplinar entre as diversas áreas das licenciaturas. Dos outros dois Blocos, um seria de formação específica de cada área e um terceiro pensado para atender à legislação no que se referia a horas complementares abertas e de estágio.

Estes Blocos possuíam núcleos e, dentro deles, os componentes. A organização da matriz curricular se dava com um equilíbrio de Blocos e Núcleos diferentes dentro do mesmo período, a fim de possibilitar uma construção teórica no início do curso e outra mais específica durante o curso. Este movimento possibilitaria uma sólida construção e discussão dos conceitos epistemológicos de cada área, construindo de forma lógica os conteúdos dos cursos. Além disso, promoveria uma ruptura nas ideias propostas pela 


\section{CIÊNCIAS HUMANAS}

REVISTA DO PROGRAMA DE PÓS-GRADUAĞ̈O EM EDUCAĞ̄o

\section{(1)URI|}

legislação, numa dinâmica de melhora nos custos do curso e, principalmente, de identidade de todos os cursos de licenciatura da Unoesc.

A proposta de curso construída pelo PPC 2006 trabalhou com uma dinâmica do processo da formação do professor que deveria ser, além de educador, também pesquisador e gestor, atendendo às exigências das diretrizes. Vale a pena lembrar que as diretrizes para os outros cursos de licenciatura não possuíam tal orientação na época. $\mathrm{O}$ grupo percebeu que poderia trabalhar com a pesquisa alinhavada com as horas destinadas à prática, conforme orientação do CNE/CP n.2 (2006), podendo então construir um docente pesquisador e autônomo.

Diante do cenário apresentado, em que órgãos internacionais propõem modelos que privilegiam o capitalismo em um sistema neoliberal, construímos, por meio da bibliografia estudada, a concepção de que a formação de professores deve priorizar a ideia de contribuir para que estes construam práticas inovadoras e atraentes aos alunos. Desta forma, proporcionarão o desenvolvimento humano, a cooperação, a solidariedade e o coletivo, possibilitando uma concepção de mundo no qual o indivíduo é parte e responsável pelo mesmo, compreendendo que o conhecimento influencia na formação humana e na prática social. Esta percepção dos alunos construída por meio de abordagens relacionadas à ética evitará conceitos fragmentados e sem interação.

Um projeto pedagógico poderia ser diferente, tecendo uma trama entre conhecimentos científicos e conhecimentos voltados às humanidades. O relacionamento entre os temas possibilitaria o que se denomina inter, multi ou pluridisciplinariedade, tendo como pano de fundo questões postas por um sistema como o capital e suas consequências. Na opinião de Silva e Catalão (2015, p. 261) "Em questão está o "desafio da globalidade", pois há um distanciamento entre os "elementos" compartimentados das disciplinas e as realidades multidimensionais [...] que nos leva a separar (os objetos dos seus meios, as disciplinas umas das outras) e não reunir".

Perante este desafio, faz-se necessário reorganizar o Projeto Político Pedagógico do curso de Pedagogia, priorizando a horizontalização dos conteúdos. Essa construção poderá ser discutida em todos os níveis, desde o legislativo e o pedagógico, principalmente priorizando a fala dos que estão na ponta do processo e que irão 


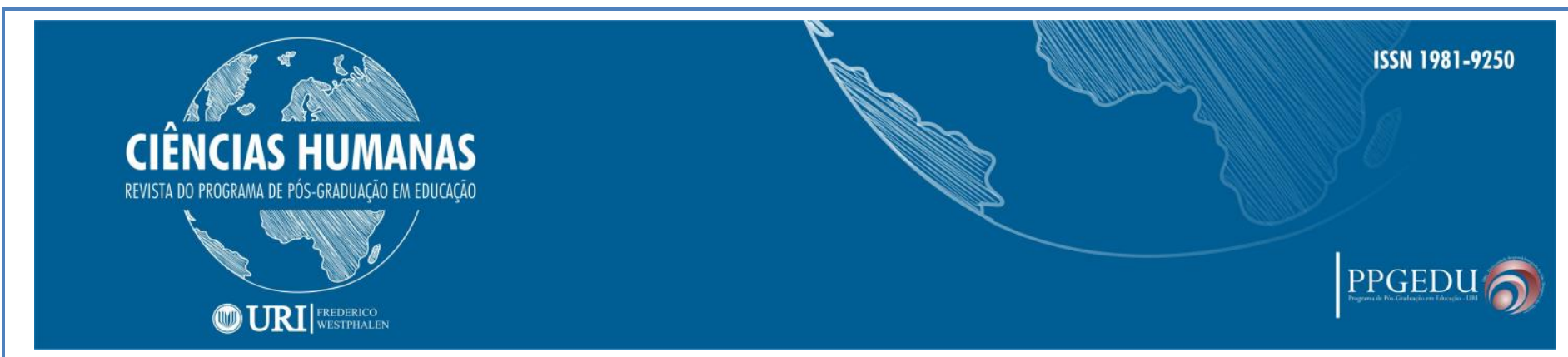

realmente dar vida ao que será proposto. Assim, tentaríamos buscar alternativas para que o futuro de cursos formadores, que Gramsci chama de Homo sapiens e não Homo faber, seja concretizado. Além de escutar os protagonistas do processo histórico, a visão que se pode ter das ações paralelas ao processo direto de ensino precisa ser considerada por meio da complementação do que é estudado em sala de aula.

Por meio destes direcionamentos na construção de novas DCN’s, Borges (2010) identifica uma possível alternativa, integrando uma formação desejada com as condições impostas para a formulação dos Projetos Políticos Pedagógicos dos cursos de Pedagogia, por meio das Diretrizes Curriculares norteadas em meio de políticas neoliberais. A autora (BORGES, 2010, p. 37) defende que o meio para esta integração é a Pesquisa, onde "a produção de um conhecimento de base empírica... por meio da dúvida gerada no campo da prática, [...] torna-se componente curricular referencial para o futuro professor conhecer a realidade na qual se insere a fim de poder transformá-lo". Dessa maneira, um professor pode ser capaz de superar o que ensina e ir além de seu repertório.

\section{REFERÊNCIAS}

AGUIAR, Márcia Angela da S. et al. Diretrizes Curriculares do curso de Pedagogia no Brasil: disputas de projetos no campo da formação do profissional da educação.

Campinas: Unicamp - Educação \& Sociedade, v. 27, n. 96 Especial, p. 819-842, out. 2006. Disponível em: <http://www.scielo.br/pdf/es/v27n96/a10v2796.pdf> Acesso em: 30 de nov. 2015.

ANDERSON, Perry. Balanço do Neoliberalismo. In: SADER, Emir; GENTILI, Pablo. Pós-neoliberalismo: as políticas sociais e o estado democrático. Rio de Janeiro: Paz e Terra, 1995.

BORGES, Lívia F. F. Um currículo para a formação de professores. In: VEIGA, Ilma, P. A.; SILVA, Edileuza F. da. A escola mudou. Que mude a formação de professores. Campinas: Papiros, 2010. Cap. 2, p. 35-60.

BORÓN, Atílio. A sociedade civil depois do dilúvio neoliberal. In: SADER, Emir; GENTILI, Pablo. Pós-neoliberalismo: as políticas sociais e o estado democrático. Rio de Janeiro: Paz e Terra, 1995.

BRASIL. Ministério da Educação e Cultura. Lei de Diretrizes e Bases da Educação Nacional n. 9394/96. Brasília: MEC, 1996.

\begin{tabular}{l|c|c|c}
\hline Rev. Ciências Humanas & Frederico Westphalen, RS & Pg. 92 - 117 & mai./ago. 2018 \\
\hline
\end{tabular}

\begin{tabular}{l|l} 
Recebido em: 30/08/2018 & Aceito em: 17/10/2018
\end{tabular}




\section{CIÊNCIAS HUMANAS}

REVISTA DO PROGRAMA DE PÓS-GRADUAĞ̈O EM EDUCAĞ̄o

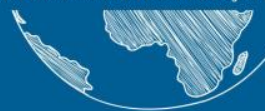

(10)URI| |rRDERco

BRASIL. Resolução CNE/CP N 1, de 15 de maio de 2006. Disponível em:

<http://portal.mec.gov.br/cne/arquivos/pdf/rcp01_06.pdf> Acesso em 30/04/2016

BRITO, Eliana Povoas; HEIDEN, Roberto. Entre a reestruturação e a expansão das Universidades Federais: movimentos que singularizam a travessia da UFPEL. São Paulo: Biblioteca Anpae. Série Cadernos: n.11, 2011. Disponível em: < http://www.anpae.org.br/simposio2011/cdrom2011/PDFs/> Acesso em: 29 de nov. 2015.

CASAGRANDE, Ieda M. K., PEREIRA, Sueli M., SAGRILLO, Daniele R. O Banco Mundial e as políticas de formação docente no Brasil. Campinas: ETD, v. 16. n. 3, p. 494-512, set./dez. 2014. Disponível em:

<https://www.fe.unicamp.br/revistas/ged/etd/article/view/6700> Acesso em: 30 de nov. 2015.

CHAVES, Vera Lúcia Jacob. Expansão da privatização/mercantilização do ensino superior brasileiro: a formação dos oligopólios. Campinas: Unicamp - Educação \& Sociedade, v. 31, n. 111, p. 481-500, abr.-jun. 2010. Disponível em:

<http://www.scielo.br/pdf/es/v31n111/v31n111a10.pdf> Acesso em: 25 de abr. 2016.

FREITAS, Helena Costa Lopes de. A (nova) política de formação de professores: a prioridade postergada. Campinas: Unicamp - Educação \& Sociedade, v. 28, n. 100 Especial, p. 1203-1230, out. 2007. Disponível em: < www.scielo.br/pdf/es/v28n100/a2628100.pdf> Acesso em: 29 de nov. 2015.

FRIGOTTO, G. Reformas educativas e o retrocesso democrático no Brasil nos anos 90. In: LINHARES, Célia (Org.). Os professores e a reinvenção da escola: Brasil e Espanha. São Paulo: Cortez, 2001b.

GASPARIN, João Luiz. Uma Didática para a Pedagogia Histórico-Crítica. Campinas: Autores Associados, 2002.

GATTI, Bernardete A. Educação, escola e formação de professores: políticas e impasses. Curitiba: Editora UFPR - Educar em Revista, n. 50, p. 51-67, out./dez. 1015. Disponível em: < http://www.scielo.br/pdf/er/n50/n50a05.pdf > Acesso em: 30 de nov. 2015.

GENTILI, Pablo. O direito à educação e as dinâmicas de exclusão na América Latina. Educ. Soc., Campinas, vol. 30, n. 109, p. 1059-1079, set./dez. 2009 Disponível em: <http://www.cedes.unicamp.br> Acessado em 21 de setembro de 2016.

KOSIK, Karel. Dialética do Concreto, $7^{\text {a }}$ ed., São Paulo: Paz e Terra, 2002.

LIBÂNEO, José Carlos. Diretrizes Curriculares da Pedagogia: imprecisões teóricas e concepção estreita da formação profissional de educadores. Campinas: Unicamp - 
Educação \& Sociedade, v. 27, n. 96 Especial, p. 843-876, out. 2006. Disponível em: < http://www.scielo.br/pdf/es/v27n96/a11v2796.pdf> Acesso em: 30 de nov. 2015.

MAUÉS, Olgaíses. Formação e Trabalho Docente na Educação Superior. In: SILVA JUNIOR, João dos Reis et al. (org) Educação Superior: Internacionalização, mercantilização e repercussões em um campo de disputas. Belo Horizonte: Fino Traço, 2015. Parte IV, cap 1, p. 205-228.

McCOWAN, Tristan; SCHENDEL, Rebecca. A mudança do papel da universidade e seu impacto na sociedade em países de baixa renda. In: SILVA JUNIOR, João dos Reis et al. (org) Educação Superior: Internacionalização, mercantilização e repercussões em um campo de disputas. Belo Horizonte: Fino Traço, 2015. Parte I, cap 1, p. 19-48.

MÉSZÁROS, Instván. A educação para além do capital. São Paulo: Boitempo, 2008.

OLIVEIRA, Silvia A. de P.; ALMEIDA, Maria de L. P.; Educação para o mercado do trabalho: impasses e contradições. In: ALMEIDA, Maria de L. P.; SOUZA, Sônia R.; Políticas de educação e processos pedagógicos contemporâneos no Brasil. Campinas: Mercado de Letras, 2011.

PEREIRA, Júlio Emílio Diniz. As licenciaturas e as novas políticas educacionais para a formação docente. Campinas: Unicamp - Educação \& Sociedade, v. 20, n. 68, p. 109125, dez. 1999 Disponível em: 〈http://www.scielo.br/pdf/es/v20n68/a06v2068.pdf> Acesso em: 30 de nov. 2015.

SAVIANI, Dermeval. Escola e Democracia. Campinas: São Paulo. Autores Associados, 2008.

SAVIANI, Dermeval. Pedagogia Histórico-Crítica: primeiras aproximações. Campinas: Autores Associados, 2000.

SAVIANI, Dermeval. Da nova LDB ao FUNDEB: por uma outra política educacional. Campinas: Autores Associados, 2007.

SCHEIBE, Leda. Diretrizes Curriculares para o curso de Pedagogia: trajetória longa e inconclusa. São Paulo: Fund. Carlos Chagas - Cadernos de pesquisa, v. 37, n.130, p. 43-62, jan./abr. 2007. Disponível em: < http://www.scielo.br/pdf/cp/v37n130/04.pdf> Acesso em 30 de nov. de 2015.

SCHNEIDER, Marilda Pasqual; DURLI, Zenilde; NARDI, Elton Luiz. Reforma dos cursos de formação de professores: relações entre as políticas curriculares e a prática pedagógica. Porto Alegre: Educação, v. 32, n. 3, p. 331-338, set./dez. 2009. Disponível em: < http://revistaseletronicas.pucrs.br/ojs/index.php/faced/article/view/4946/4189> Acesso em 29 de nov. de 2015. 
SGUISSARDI, Valdemar. Modelo de expansão da Educação Superior no Brasil: predomínio privado/mercantil e desafios para a regulação e a formação universitária. Campinas: Unicamp - Educação \& Sociedade, v. 29, n. 105, p. 991-1022, set./dez. 2008. Disponível em: < http://www.scielo.br/pdf/es/v29n105/v29n105a04.pdf> Acesso em 23 de set. de 2016.

SHIGUNOV NETO, Alexandre; MACIEL, Lizete Shizue Bomura. Formação de Professores. São Paulo: Cortez, 2004.

SILVA, Maria Abádia da. Intervenção e consentimento: a política educacional do Banco Mundial. Campinas: Autores Associados, 2002.

SILVA, Rosana Gonçalves da; CATALÃO, Vera Margarida Lessa. Religação de saberes e educação: as contribuições do pensamento complexo. In: SILVA, Maria Abádia da; SILVA, Kátia A. C. P. Cordeiro da. (Org.) Pensamento político e pedagógico na formação do pesquisador em educação. Belo Horizonte: Fino Traço, 2015 .

SILVA, Tomaz Tadeu da. Escola S.A. Quem ganha e quem perde no mercado educacional do neoliberalismo. Brasília: CNTE, 1999.

STROBEL NETO, Walter; ALMEIDA, Maria de Lourdes Pinto de. Políticas de Educação Superior e Formação de Professores. Campinas: Marcado de Letras, 2017.

TRIVIÑOS, Augusto Nibaldo Silva. Introdução à pesquisa em ciências sociais: a pesquisa qualitativa em educação. São Paulo: Atlas, 2011.

VEIGA, Ilma P. A. A aventura de formar professores. Campinas: Papirus, 2009.

VEIGA, Ilma P. A.; VIANA, Cleide M. Q. Q. Formação de Professores: um campo de possibilidades inovadoras. In: VEIGA, Ilma, P. A.; SILVA, Edileuza F. da. A escola mudou. Que mude a formação de professores. Campinas: Papiros, 2010. Cap. 1, p. 13-34.

WAISMANN, Moisés; CORSETTI, Berenice. O Banco Mundial e as políticas públicas para a educação superior no Brasil. In: SILVA JUNIOR, João dos Reis et al. (org)

Educação Superior: Internacionalização, mercantilização e repercussões em um campo de disputas. Belo Horizonte: Fino Traço, 2015. Parte II, cap 3, p. 119-138. 